\title{
Measurement of Environmental Performance Index: A Case Study of Thane City
}

\author{
Dr (Mrs) Lina R.Thatte ${ }^{1}$, Ms H.A.Chande ${ }^{2}$ \\ ${ }^{I}$ (Associate Professor and Head, Department of Economics, K.E.T.'s V .G. Vaze College of Arts, Science and \\ Commerce, Mulund, Mumbai, India) \\ ${ }^{2}$ ( Assistant Professor, Department of Economics, Sheth N.K.T.T. College of Commerce and Sheth J.T.T. \\ College of Arts, Thane, India)
}

\begin{abstract}
Environmental status reporting is crucial for measurement of environmental quality and performance. Today for every city in India, publication of environmental status report (ESR) is mandatory. However, it is important to know how far the cities report exhaustively about all the variables impacting environment and thus enable us to get the correct picture of environmental performance. Maharashtra Pollution Control Board has developed an Indicator Framework Approach to evaluate ESRs and construct environment performance index (EPI). In this paper, we have applied MPCB's methodology to assess Thane Municipal Corporation's (TMC's) environmental reporting and performance using the data provided in ESR of 2012. We found that EPI of Thane is modest and based on inadequate data. We recommend that TMC needs to improve environmental reporting as well as performance of Thane city.
\end{abstract}

Keywords: Environment Performance Index, Growth of Cities, Initiatives for improving city environment , State of Natural Resources, state of Urban services

\section{Introduction}

Sustainable urban development can be defined as development that improves the long term social and ecological health of cities and towns. The difficult challenge facing planners comes with the implementation of sustainability visions, policy and programs, and in the midst of doing so, the need to modify institutions to achieve these goals. Appropriate policy making, implementation and efficiency of delivery systems needs to be evaluated by identifying and assessing the impacts of various measures undertaken by the urban local bodies. Information on the economic values of policy changes with regard to the environment can greatly assist in identifying the policy and sectoral priorities. Economic valuation incorporating environmental aspects helps in evaluating developmental projects, programs and policies. It acts as a pointer to weaknesses in policy implementation and at the same time, can enhance the measures and reinforce local bodies to further their efforts for the city's sustainable development.

Below, in section 2, we specify the objectives of our paper, in 3, we note the hypotheses of our study, in section 4, we describe the indicator framework approach, in section 5, we construct Environmental Performance Index (EPI) of Thane city and in 6, we conclude.

\section{Objectives}

1. To study environmental status reporting done by Thane Municipal Corporation.

2. To construct Environment Performance Index of the Thane city.

\section{Hypotheses}

1. Reporting of environmental status by TMC is inadequate.

2. Environmental performance Index of Thane city is below threshold level.

\section{Indicator Framework Approach}

In the context of 74th Constitutional Amendment Act (CAA), the impact evaluation of environmental management measures undertaken by civic bodies is mandatory. Preparation and publication of environmental status reports (ESRs) is compulsory. Environmental reporting finds its roots in the Local agenda 21 mandate that was passed in the Earth Summit of 1992 in Rio.

In case of Thane city, Maharashtra, India, Thane Municipal Corporation (TMC) prepares and publishes ESRs every year and Maharashtra Pollution Control Board (MPCB) monitors the environmental status in the region. In 2009, MPCB has developed a region-specific methodology called Indicator Framework Approach for evaluating the environmental reporting and performance of cities. 
MPCB's indicators framework has a pyramidal structure that is represented in fig. 1 below. At the base of the indicator pyramid are the data variables. The data variables are translated to preliminary indicators under various thematic groups. The entire preliminary indicators under same theme add up to give the thematic score. Adding up scores of thematic indicators finally gives the apex score, that is, the Environmental Performance Index (EPI) [1].

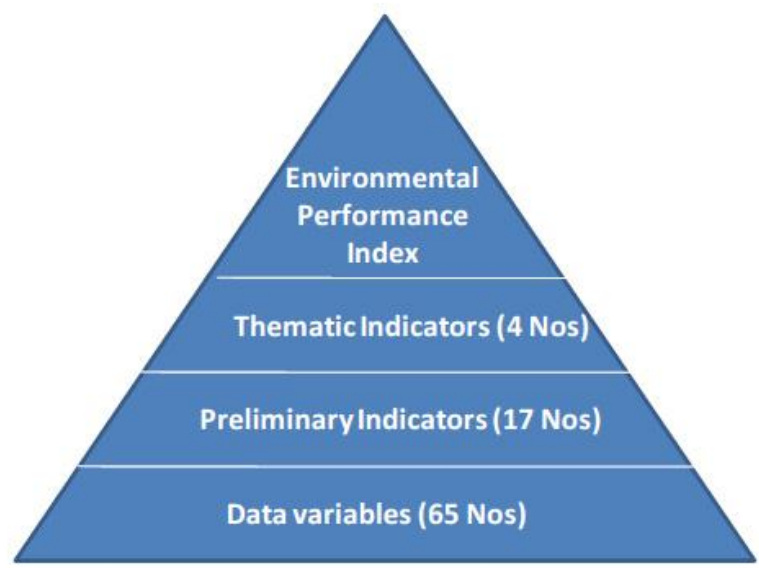

Figure 1: Levels of Indicators (Source: MPCB report, June 2009)

The scoring is proposed in such a way that maximum of the score will show the best environmental performance of the city. Weights are defined as per the contribution of that theme into city environment. For example, state of natural resources is the most critical in the city environment. Thus it has been given highest weightage of 30 percent. Weights assigned to the entire four themes sum up to 100. The weights given to thematic indicators are as follows:

i. Growth of Cities- weightage 25,

ii. State of Natural Resources- weightage 30,

iii. State of Urban services-weightage 25 and

iv. Initiatives for improving city environment-weightage 20.

Similarly data variables belonging to all the preliminary indicators under a particular theme are also assigned weights based on the extent of availability of information in the ESRs. These weights attached to available data variables are adjusted or redistributed such that the total of these weights is equal to the weight assigned to the theme.

There are total 65 data variables in the MPCB approach. The preliminary indicators under growth of cities theme include: demographic, economic, industrial and spatial growth; state of natural resources theme include: land, air, water, energy and humans; urban services theme include: water supply, sanitation, transport and solid waste management and the initiatives for improving city environment theme includes: Environment education, waste management, and traffic and slum improvement.

\subsection{Scoring Scheme}

To enable scoring, Benchmarks were defined for each data variable. These benchmarks were completed using various sources of information from literature. For all the data related to the demography, benchmarks are defined by using Census figures for State and Country. For all the data variables related to natural resources the benchmark values have been defined using standards defined by various agencies like MPCB, Central Pollution Control Board (CPCB), Urban Development Plans Formulation and Implementation (UDPFI) Guidelines, Central Public Health and Environmental Engineering Organization (CPHEEO) etc. for the variables related to urban services the benchmarks are defined by referring to various studies conducted. E.g. studies by agencies like Asian Development Bank (ADB), Maharashtra Energy Development Agency (MEDA) etc. The data for which benchmarks were not available; E.g. Percentage of slum area to city area or annual fuel consumption ofthe city; intercity comparison was used to arrive at working level benchmarks. Scoring of the variable against benchmark is dependent upon whether that variable is pro environment. For all the pro environment variables, higher the value than benchmark, better is the score and vice versa.

\section{Environment Performance Index of Thane City}

We computed environmental performance index (EPI) of Thane city by applying the MPCB's indicators framework approach elaborated in earlier section. We used the data reported in ESR of TMC for the year 2012 for computing EPI. We note below the scores acquired under four themes. 
5.1 Theme: Growth of city (weight- 25)

The scoring pattern for the theme of growth of city is done in four components as given in the table 1 below.

Table 1: Scoring for growth of city theme

5.1.1Component I: Demographic growth.

\begin{tabular}{|l|l|l|l|l|}
\hline Sr. No. & Data variable & $\begin{array}{l}\text { Score/rating } \\
\text { for Thane }\end{array}$ & $\begin{array}{l}\text { Redistributed } \\
\text { Weight }\end{array}$ & $\begin{array}{l}\text { Weighted } \\
\text { Score }\end{array}$ \\
\hline 1 & Decadal population growth (\%) & 2 & 6.25 & 12.5 \\
\hline 2 & Growth in migrated population & 0 & 0 & 0 \\
\hline 3 & \% of slum population to the total & 2 & 6.25 & 12.5 \\
\hline & & & Total score (I) & 25.0 \\
\hline
\end{tabular}

The rating for decadal population growth is taken as 2 as the prescribed score is 2 for a growth rate $>30 \%$ and in case of Thane it is as high as 55\%. Total slum population reported in ESR 2012 is 7.56 lacks; Percentage of slum population to the total worked out to be $38 \%$, and thus gets a score of 2 [2].

\subsubsection{Component II: Economic growth}

\begin{tabular}{|l|l|l|l|l|}
\hline Sr. No. & Data variable & $\begin{array}{l}\text { Score/rating } \\
\text { for Thane }\end{array}$ & $\begin{array}{l}\text { Redistributed } \\
\text { Weight }\end{array}$ & $\begin{array}{l}\text { Weighted } \\
\text { Score }\end{array}$ \\
\hline 1 & Work participation ratio & 0 & 0 & 0 \\
\hline 2 & $\%$ population BPL & 0 & 0 & 0 \\
\hline 3 & Average annual PCI & 0 & 0 & 0 \\
\hline 4 & $\begin{array}{l}\% \text { of budget spent on environmental } \\
\text { infrastructure }\end{array}$ & 2 & 6.25 & 12.5 \\
\hline & & Total score (II) & 12.5 \\
\hline
\end{tabular}

MPCB's criteria for \% of budget spent on environmental infrastructure considers solid waste management, sewage treatment and bio medical waste management, but since Bio-medical waste is managed by NGO, envirovigil , data on that was not reported in budget. Since only $11.18 \%$ of budget of TMC (average of 2009-12 was taken for solid waste management and sewage treatment) was spent on environmental infrastructure, it is assigned a rating of 2, and Variables that were not reported in the ESR are given the rating/score of zero.

\subsubsection{Component III: Industrial growth}

\begin{tabular}{|l|l|l|l|l|}
\hline Sr. No. & Data variable & $\begin{array}{l}\text { Score/rating } \\
\text { for Thane }\end{array}$ & $\begin{array}{l}\text { Redistributed } \\
\text { Weight }\end{array}$ & $\begin{array}{l}\text { Weighted } \\
\text { score }\end{array}$ \\
\hline 1 & $\begin{array}{l}\text { \% share of industries in total electricity } \\
\text { Consumption }\end{array}$ & 8 & 6.25 & 50 \\
\hline 2 & Number of polluting Industries & 0 & 0 & 0 \\
\hline & & & Total score (III) & 50 \\
\hline
\end{tabular}

Share of industries in total electricity consumption is $25.43 \%$, hence it is assigned a score of 8 , and since data for $\%$ of polluting industries to total industries is not available it is assigned a score of zero.

\subsubsection{Component IV: Spatial growth}

\begin{tabular}{|c|c|c|c|c|}
\hline Sr. No. & Data variable & $\begin{array}{l}\text { Score/rating } \\
\text { for Thane }\end{array}$ & $\begin{array}{l}\text { Redistributed } \\
\text { Weight }\end{array}$ & $\begin{array}{l}\text { Weighted } \\
\text { score }\end{array}$ \\
\hline 1 & Population density & 2 & 6.25 & 12.5 \\
\hline \multirow[t]{2}{*}{2} & $\%$ of slum area to city area & 0 & 0 & 0 \\
\hline & & & Total score (III) & 12.5 \\
\hline
\end{tabular}

Population density in Thane is24, 218 persons/ sq. km, which is > 1000 persons and is thus given a lower prescribed rating of 2. Data on \% of slum area to city area is not available and hence it is assigned a score of zero.

Total score for growth of city theme (Component I to IV) $=25+12.5+50+12.5=100$

\subsection{Theme: State of natural resources (weight- 30)}

The scoring pattern for this theme is done in five components as represented below in table 2 .

Table2: Scoring for state of natural resources theme

\subsubsection{Component I: Land}

\begin{tabular}{|l|l|l|l|l|}
\hline Sr. No. & Data variable & $\begin{array}{l}\text { Score/rating } \\
\text { for Thane }\end{array}$ & $\begin{array}{l}\text { Redistributed } \\
\text { Weight }\end{array}$ & $\begin{array}{l}\text { Weighted } \\
\text { score }\end{array}$ \\
\hline 1 & Land use & 10 & 3.75 & 37.5 \\
\hline 2 & \% of green area to total city area & 10 & 3.75 & 37.5 \\
\hline 3 & Green area per1000 persons & 10 & 3.75 & 37.5 \\
\hline & & & Total score (I) & 112.5 \\
\hline
\end{tabular}


In case of land use, the 2012 ESR of Thane reports seven parameters of land use, namely residential, industrial, protected area, forest area, green cover, roads and reserved area and is thus given a rating of 10 . The city's green area to total comes to $52.81 \%$ and $3.72 \mathrm{Ha}$ green area per 1000 persons. The rating of 10 was applicable for $>20$ $\%$ of green area to total city area and score of 10 for $>2 \mathrm{Ha}$. of green area per 1000 persons.

\subsubsection{Component II: Air}

\begin{tabular}{|l|l|l|l|l|}
\hline $\begin{array}{l}\text { Sr. } \\
\text { No. }\end{array}$ & Data variable & $\begin{array}{l}\text { Score/rating } \\
\text { for Thane }\end{array}$ & $\begin{array}{l}\text { Redistributed } \\
\text { Weight }\end{array}$ & Weightedscore \\
\hline 1 & Ambient air Quality & 8 & 3.75 & 30 \\
\hline 2 & Noise & 2 & 3.75 & 7.5 \\
\hline & & & Total score (II) & 37.5 \\
\hline
\end{tabular}

TMC's ESRs have reported at least five parameters for ambient air quality in their ESR and thus a rating of 8 was given. The ESRs of TMC report monitoring of pollutant levels in both residential areas across nodes as well as at traffic junctions.Levels of respirable particulate matter (RSPM), sulphur dioxide (SO2), nitrogen dioxide (NOx), Ammonia (NH3) and Hydrogen di-sulfide (H2 S) are reported parameters for ambient air quality in TMC's ESRs.

The data variable noise gets a low score of 2 since Noise level monitored at 11 different main squares in the region (100\% of the critical junctions) do not comply with the noise level standards prescribed for commercial areas as $65 \mathrm{~dB}(\mathrm{~A})$, and also Noise Level Monitored at 12 different Silence Zones (100\%) do not comply with the noise level standards for silence zones prescribed as $50 \mathrm{~dB}$ (A).

\subsubsection{Component III: Water}

\begin{tabular}{|l|l|l|l|l|}
\hline Sr. No. & Data variable & $\begin{array}{l}\text { Score/rating } \\
\text { for Thane }\end{array}$ & $\begin{array}{l}\text { Redistributed } \\
\text { Weight }\end{array}$ & $\begin{array}{l}\text { Weighted } \\
\text { Score }\end{array}$ \\
\hline 1 & \% of untreated industrial effluent discharged & 0 & 0 & 0 \\
\hline 2 & Water quality- lakes & 10 & 3.75 & 37.5 \\
\hline 3 & Water quality- sea & 0 & 0 & 0 \\
\hline 4 & Water quality- river & 0 & 0 & 0 \\
\hline & & & Total score (III) & 37.5 \\
\hline
\end{tabular}

The data variable of water quality has been given a high rating of 10 since nine parameters have been reported in the ESRs against the average of 8 prescribed by MPCB.

\subsubsection{Component IV: Energy}

\begin{tabular}{|l|l|l|l|l|}
\hline Sr. No. & Data variable & $\begin{array}{l}\text { Score/rating } \\
\text { for Thane }\end{array}$ & $\begin{array}{l}\text { Redistributed } \\
\text { Weight }\end{array}$ & $\begin{array}{l}\text { Weighted } \\
\text { Score }\end{array}$ \\
\hline 1 & Per capita energy Consumption (Kwh/Annum) & 10 & 3.75 & 37.5 \\
\hline 2 & \% share of renewable energy & 0 & 0 & 0 \\
\hline 3 & Annual fuel Consumption & 2 & 3.75 & 7.5 \\
\hline & & & Total score (IV) & 45 \\
\hline
\end{tabular}

Energy consumption for residents as given in ESR 2012 is 62.83 MW for 2011-12, converting into Per capita energy Consumption (Kwh/Annum), it is $0.0345(62.83 * 1000=62,830$ dividing by population $18,18,872$ it is $0.0345)$, as it is less than 300 , hence a maximum score of 10 is given.

Annual fuel consumption for 2011-12 is 287 lakh lts which is much higher than the maximum usage of $>5$ lakh lts shown for minimum score of 2 , and hence a minimum score of 2 is given.

\subsubsection{Component V: Humans}

\begin{tabular}{|l|l|l|l|l|}
\hline Sr. No. & Data variable & $\begin{array}{l}\text { Score/rating } \\
\text { for Thane }\end{array}$ & $\begin{array}{l}\text { Redistributed } \\
\text { Weight }\end{array}$ & $\begin{array}{l}\text { Weighted } \\
\text { score }\end{array}$ \\
\hline 1 & Crude death rate & 0 & 0 & 0 \\
\hline 2 & Infant mortality Rate & 0 & 0 & 0 \\
\hline & & & Total score (V) & 0 \\
\hline
\end{tabular}

Data variables in component $\mathrm{V}$ are not given in the ESR.

Total score for state of natural resources theme (Component I to $\mathrm{V})=112.5+37.5+37.5+45+0=232.5$

5.3 Theme: Urban services (weight- 25)

The score for this theme is done in four components as represented below in table 3. 
Table 3: scoring for urban services theme

\subsubsection{Component I: Water supply}

\begin{tabular}{|l|l|l|l|l|}
\hline Sr. No. & Data variable & $\begin{array}{l}\text { Score/rating } \\
\text { for Thane }\end{array}$ & $\begin{array}{l}\text { Redistributed } \\
\text { Weight }\end{array}$ & $\begin{array}{l}\text { Weighted } \\
\text { score }\end{array}$ \\
\hline 1 & Net water supply (LPCD) & 10 & 2.273 & 22.73 \\
\hline 2 & $\begin{array}{l}\text { \% of households connected } \\
\text { by service connection }\end{array}$ & 10 & 2.273 & 22.73 \\
\hline 3 & Unaccounted for water (\%) & 0 & 0 & 0 \\
\hline 4 & Staff/1000 connections & 0 & 0 & 0 \\
\hline 5 & Average water tariff & 10 & 2.273 & 22.73 \\
\hline & & & Total score (I) & 68.19 \\
\hline
\end{tabular}

The net water supply is 251 liters per capita per day (lpcd) and is above 150 lpcd and thus gets a score of 10 . The average water tariff worked out is RS.6.40, which is greater than 5, so maximum score of 10 is assigned. There are 3,95,971 connections and water supply network covers 99\% geographical area of the Corporation, hence score for $\%$ of households connected by service connections is given as 10 , as it is greater than $30 \%$. (Average water tariff is Rs 5 for $1 \mathrm{KL}$ upto 20,000 litres ,Rs 6.5 for consumption between 20,000 to 24,000 liters and Rs 8 for above 24,000 liters consumption, and slum population for thane is $38 \%$, so $5 * 0.38=1.9$, and remaining population is $62 \%$ so average tariff for remaining population is taken as 4.50 , as $6.5+8=7.25$, and $7.25 * 0.62=4.50$ ) [3], average water tariff for entire population is worked out as $1.9+4.5=6.4$, it is $>5$ and hence a score of 10 is given.

\subsubsection{Component II: Sewerage and sanitation}

\begin{tabular}{|l|l|l|l|l|}
\hline Sr. No. & Data variable & $\begin{array}{l}\text { Score/rating } \\
\text { for Thane }\end{array}$ & $\begin{array}{l}\text { Redistributed } \\
\text { Weight }\end{array}$ & $\begin{array}{l}\text { Weighted } \\
\text { Score }\end{array}$ \\
\hline 1 & \% of treated sewage & 4 & 2.273 & 9.09 \\
\hline 2 & \% area covered for sewage & 2 & 2.273 & 4.55 \\
\hline 3 & $\begin{array}{l}\text { \% of population catered by } \\
\text { underground sewer network }\end{array}$ & 0 & 0 & 0 \\
\hline 4 & $\begin{array}{l}\text { \% of slum population served by pay and use } \\
\text { toilets }\end{array}$ & 0 & 0 & 0 \\
\hline 5 & Staff/1000 connections & 0 & 0 & 0 \\
\hline & & & Total score (II) & 13.64 \\
\hline
\end{tabular}

Percentage of treated sewage is 40.76\% (120 MLD treated out of 294.4MLD generated, ESR 2012, pg.12 for treated sewage) and hence a score of 4 is given and \% area covered for sewage in Thane is 17\% (ESR 2012, pg 30) ,hence a minimum score of 2 is given.

[(Total sewage generated is calculated as per formula in Thane City Sanitation Plan (CSP)pg 51 [4]

Total water supplied is 460 MLD (2011-12), total Sewage generated is

$460 * 0.8=368 \mathrm{MLD}$ (Actual water received after distribution losses)

$368 * 0.8=294.4$ MLD (Sewage generated) $]$

\subsubsection{Component III: Solid waste management}

\begin{tabular}{|l|l|l|l|l|}
\hline Sr. No. & Data variable & $\begin{array}{l}\text { Score/rating } \\
\text { for Thane }\end{array}$ & $\begin{array}{l}\text { Redistributed } \\
\text { Weight }\end{array}$ & $\begin{array}{l}\text { Weighted } \\
\text { Score }\end{array}$ \\
\hline 1 & Solid waste generation per capita & 6 & 2.273 & 13.64 \\
\hline 2 & Life of landfill site & 0 & 0 & 0 \\
\hline 3 & $\%$ waste disposed to landfill site & 0 & 0 & 0 \\
\hline 4 & Collection efficiency (\%) & 10 & 2.273 & 22.73 \\
\hline 5 & \% biomedical waste treated to the Total & 10 & 2.273 & 22.73 \\
\hline 6 & \% of wet waste treated to the total & 0 & 0 & 0 \\
\hline 7 & Compliance with MSW rules & 0 & 0 & 0 \\
\hline & & & Total score (III) & 59.10 \\
\hline
\end{tabular}

Solid waste generation is 650 MT, as per ESR 2012 pg 15, and considering population of Thane as 18,18,872 for 2011 , the solid waste generation per capita is worked out, which is 357.36 grams $(65,00,00,000 / 18,18,872)$, this being in between 351-400 grams range, score assigned is 6 .

Since Household level coverage of solid waste management services is $100 \%$ as mentioned in TMC website, that is, greater than $85 \%$, a score of 10 was assigned for collection efficiency. As mentioned in website of TMC there are around 256 Hospitals and 1056 dispensaries in TMC area, which generates 900 to $950 \mathrm{~kg}$ of BioMedical waste and as per the guidelines of Bio-Medical waste Rule 1998, the same is disposed off in the 
incinerator. This activity is subcontracted to the NGO, Enviro Vigil on B.O.T. basis, so Percentage of biomedical waste treated is to be considered as 100 , and hence a score of 10 is given.

In case of \% of wet waste treated to the total, ESR $2012 \mathrm{pg} 13$ mentions of Biomethanisation Plant of 15 MT capacity at Chatrapati Shivaji Maharaj Hospital and a 5 MT capacity plant at Hiranandani Estate, Patlipada, but it does not mention about amount of wet waste generated, hence 0 score is given. Similarly ESR mentions that Thane Municipal Corporation does not have its own dumping ground and mentions problems related to landfill site and does not mention about Life of landfill site, \% waste disposed to landfill site and also about Compliance with MSW rules and hence a score given is 0

\subsubsection{Component IV: Transportation}

\begin{tabular}{|l|l|l|l|l|}
\hline Sr. No. & Data variable & $\begin{array}{l}\text { Score/rating } \\
\text { for Thane }\end{array}$ & $\begin{array}{l}\text { Redistributed } \\
\text { Weight }\end{array}$ & $\begin{array}{l}\text { Weighted } \\
\text { Score }\end{array}$ \\
\hline 1 & \% of road area to city area & 2 & 2.273 & 4.55 \\
\hline 2 & \% of population travelling by public Transport & 2 & 2.273 & 4.55 \\
\hline 3 & \% of public vehicles running on CNG & 4 & 2.273 & 9.09 \\
\hline & & & Total score (IV) & 13.64 \\
\hline
\end{tabular}

As mentioned on pg 1 of ESR 2012, total area under road is 742.97 hectare out of total area of 12823.00 hectare, which works out to be 5.79 percent of the total hence a score of 2 is given. As mentioned in the website of TMC, population travelling by public Transport per day is 2, 55,000 (2011-12), Comparing this to the total, the $\%$ of population travelling by public transport is $14.02 \%$, which is < $40 \%$ and hence a lower rating of 2 is assigned. ESR 2012 pg 27, mentions that in the financial year 2011- 12 Thane Municipal Transport Service has 321 buses, out of which number of buses running on CNG is 128 which works out to be $39.88 \%$ of the total, hence a score of 4 is given.

Total score for urban services theme $($ Component I to IV $)=68.19+13.64+59.10+13.64=154.57$

\subsection{Theme: Initiatives for improving city environment (weight- 20)}

This theme includes a set of questions to be answered as either 'yes' or 'no' In case of 'yes', a score of 8 was to be given per statement or question and in case of 'no', score to be given was 2 .

Out of twenty statements indicating initiatives in the areas of environmental education, waste management, slum improvement and traffic, eleven initiatives are found to be taken by TMC, that is, $55 \%$. On a $0-10$ point scale, the score can be assigned as 5.5 and the weight for the theme is 20 . Thus the weighted score for this theme comes to $\mathbf{1 1 0 .}$

The EPI for Thane for the year 2012 was then worked out as a summation of the total scores of the four thematic indicators.

EPI (2012) $=$ Score of themes $(\mathrm{A}+\mathrm{B}+\mathrm{C}+\mathrm{D})$

$=100+232.5+154.57+110=\mathbf{5 9 7 . 0 7}$

Table 4: weighted scores for various themes of EPI

\begin{tabular}{|l|l|l|}
\hline Theme & Weighted score for 2012 & $\begin{array}{l}\text { No. of variables on which data is unavailable in } \\
\text { 2012 ESR of TMC }\end{array}$ \\
\hline Growth of city & 100 & 06 \\
\hline State of natural resources & 232.5 & 06 \\
\hline Urban services & 154.57 & 09 \\
\hline $\begin{array}{l}\text { Initiatives for improving city } \\
\text { Environment }\end{array}$ & 110 & 09 \\
\hline EPI & 597.07 & Total = 30 \\
\hline
\end{tabular}

The EPI calculated for Thane for 2012 (EPI: 597.07) is modest, but does not reflect the true status of environmental quality as it is based on only 35 variables instead of 65 variables as required by Indicator Framework Approach.

We also computed an ideal or threshold EPI score in order to identify how far the city's environmental performance is in comparison with the "best" situation it could be in. The computation of ideal EPI applying MPCB's indicators framework was based on the assumption that all parameters are reported and their performance is as per the prescribed guidelines of the relevant agencies referred to by MPCB. For ideal/threshold EPI, the highest rating/score was given to each of the data variables, that is, a score of 10 on a 0 to 10 point scale. Weight was assigned to each variable considering the relative importance of the data variable in an indicator and in the theme; as well as, assuming that all variables are reported. Similarly for the fourth theme of initiatives for improving city environment, it was assumed that all initiatives in the areas of environmental education, waste management, slum improvement and traffic, are taken by TMC, then on a 0-10 point scale, the score assigned was 10 . Thus applying the highest ratings/scores for all data variables, the ideal EPI for Thane based on summation of the total scores of thematic indicators of growth of city (A), state of resources (B), urban services (C) and initiatives for improving city environment (D) is given below: 
Threshold EPI $=$ Score of themes $(\mathrm{A}+\mathrm{B}+\mathrm{C}+\mathrm{D})$ (1)

$=250+300+250+200=\mathbf{1 0 0 0}$

The EPI calculated for Thane for 2012 (EPI: 597.07) is well below the threshold EPI score of 1000. It is due to lack of adequate reporting of parameters as well as performances being below the prescribed levels in case of many parameters. This has proved our both hypotheses. Further, TMC's ESRs of earlier years [5] and also of 2012 seemed to have focused on reporting on measuring the levels of air pollution and taking penalizing actions against air polluters. However, pollution of environment is caused by a large number factors and data on their impact needs to be collected in ESR to get a true picture of environment quality. But this is woefully lacking in ESR of 2012.

\section{Conclusion}

In India, active measures are taken to improve environmental status reporting and measures for environmental performance. Rating of most of the parameters assessing the environmental status of Thane city as represented by the EPI scores computed on the basis of MPCB's indicators framework approach indicate that the performance of TMC is moderate. Adequate reporting of parameters as well as improved environmental performance is recommended to improve environmental status of thane city.

\section{References}

[1] Evaluation of Environmental Status Reports of Cities in Maharashtra(mpcb.gov.in/images/pdf/Evaluation_of_ESRs.pdf)

[2] EnvironmentalStatusReport,TMC,2012(www.thanecity.gov.in/uploadpdf/ESR\%202012\%20English.pdf)

[3] www.thanecity.gov.in (www.thanecity.gov.in > About TMC > Department $>$ water supply department

[4] City Sanitation Plan, TMC (www.urbanindia.nic.in/programme/uwss/csp/draft_csp/thane_csp.pdf)

[5] Environmental Status Report, TMC, 2008-09 (mpcb.gov.in/images/pdf/Thane_ESR.pdf) 